\section{In Vitro Propagation of the Rare and Endangered Grevillea scapigera (Proteaceae)}

\author{
Eric Bunn and Kingsley W. Dixon \\ Kings Park and Botanic Garden, Kings Park, West Perth, Western \\ Australia 6005
}

\begin{abstract}
Additional index words. micropropagation, leaf culture, adventitious shoots, in vivo rooting
\end{abstract}

\begin{abstract}
Micropropagation, including adventitious shoot growth from leaf sections, was achieved for Grevillea scapigera (Proteaceae), a rare and endangered species from Western Australia. Shoot tips were initiated on filter paper supports with liquid WPM (Woody Plant Medium) and supplemented with $20 \mu \mathrm{M}$ zeatin riboside and $2 \mu \mathrm{M} \mathbf{G A}_{3}$. Shoots were then incubated on WPM solidified with agar and supplemented with $5 \mu \mathrm{M}$ kinetin and $0.5 \mu \mathrm{MBA}$, which produced an approximate 6-fold multiplication rate per month. Up to three adventitious shoots were induced from $0.7-\mathrm{cm}^{2}$ leaf sections after 6 to 7 weeks on solid 1/2 MS (Murashige and Skoog) medium supplemented with 10 $\mu \mathrm{M} B A$ and $0.5 \mu \mathrm{M}$ IBA. Shoots, 30 to $50 \mathrm{~mm}$ long, were rooted in vivo in a fogged glasshouse under $70 \%$ shade using a commerical rooting powder [IBA, $0.1 \%(w / w)]$ applied to the base of the shoots. Most $(67 \%)$ of the shoots treated in this way rooted after 5 weeks. Established, rooted plants have been grown on under glasshouse conditions. Chemical names used: N6-[2-isopentenyl] adenine riboside (zeatin riboside); gibberellic acid $\left(\mathrm{GA}_{3}\right)$; 6-furfurylaminopurine (kinetin); $\mathrm{N}$-(phenylmethyl)-1H-purine6-amine (BA); 1-H-indole-3-butyric acid (IBA).
\end{abstract}

Grevillea scapigera A.S. George is an attractive, white-flowered semiprostrate shrub growing near the central wheatbelt town of Corrigin in Western Australia. A program

Received for publication 27 June 1990. Accepted for publication 20 Sept. 1991. We thank members of the Grevillea Study Group and the director and staff of the Royal Botanic Gardens, Sydney, for their efforts in preserving Grevillea scapigera. The cost of publishing this paper was defrayed in part by the payment of page charges. Under postal regulations, this paper therefore must be hereby marked advertisement solely to indicate this fact. was instigated where two grafted plants in the Royal Botanic Gardens, Sydney, were introduced to Kings Park and Botanic Garden in an attempt to propagate the species by cuttings and grafting. Since these propagation techniques met with limited success, we attempted micropropagation of the remaining grafted plants (Fig. 1).

Shoot tips and axillary nodes from side branches were taken from a whip-and-tonguegrafted plant of G. scapigera growing on a rootstock of Grevillea x 'Royal Mantle'. Shoots were washed under running tap water for $1 \mathrm{~h}$, then surface-sterilized for $5 \mathrm{~min}$ in
$0.5 \%$ sodium hypochlorite $(\mathrm{NaOCl})$ plus $0.05 \%$ Tween 80 , followed by immersion in distilled water. Bleached, damaged, or unwanted leaf and stem material was removed. Each shoot was then immersed in $0.5 \%$ $\mathrm{NaOCl}$ only for $\approx 5$ to $10 \mathrm{sec}$, washed in sterile distilled water, then placed in 30-ml polycarbonate tubes (one explant/tube) with sterile filter paper domes for support and containing $10 \mathrm{ml}$ of liquid medium. The filter paper domes were autoclaved twice at $121 \mathrm{C}$ for $15 \mathrm{~min}$. Lloyd and McCown's (1981) Woody Plant Medium (WPM) supplemented with WPM vitamins, $500 \mu \mathrm{M}$ myoinositol, $60 \mathrm{~mm}$ sucrose, $20 \mu \mathrm{M}$ zeatin riboside, and $2 \mu \mathrm{M} \mathrm{GA}$, and $\mathrm{pH} 6.0$ was autoclaved at $121 \mathrm{C}$ for $20 \mathrm{~min}$ in $250-\mathrm{ml}$ media bottles and poured into culture tubes. The tubes with their explants were incubated in the dark for 1 week.

Sterile shoot and bud cultures were moved into light provided by cool-white fluorescent tubes, $40 \mu \mathrm{mol} \cdot \mathrm{m}^{-2} \cdot \mathrm{s}^{-1}, 16 / 8 \mathrm{~h}$ light/dark. After another 3 weeks, explants were transferred to WPM as above, supplemented with $0.5 \mu \mathrm{M}$ BA or $5 \mu \mathrm{m}$ kinetin and $0.5 \mu \mathrm{M} \mathrm{BA}$, and solidified with agar at $10 \mathrm{~g}$-liter-1. Shoots averaged a 2- to 3-fold multiplication per 4week incubation period with BA alone at 0.5 $\mu \mathrm{M}$ or 5- to 6-fold with $0.5 \mu \mathrm{M} \mathrm{BA}$ and 5 $\mu \mathrm{M}$ kinetin (Table 1). Shoots of G. scapigera were mostly longer than $20 \mathrm{~mm}$ and grew vigorously; however, some required elongation and this was readily achieved on basal WPM without growth regulators. WPM medium supplemented with $1 \mu \mathrm{M} \mathrm{GA}_{3}$ and $0.5 \mu \mathrm{M}$ kinetin was used to enhance shoot development from axillary buds. Shoots were incubated, then used for root induction or further shoot proliferation.

Leaves cut from plants in vitro during the subculture procedure had petioles removed and were then incubated (under the same conditions as shoot cultures), adaxial surface up, on half-strength MS (Murashige and 


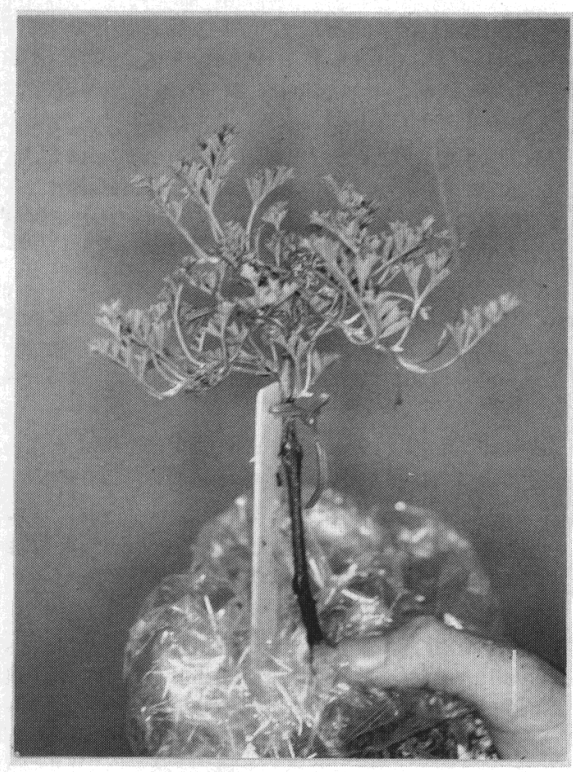

Fig. 1. Grafted plant of Grevillea scapigera from Sydney Botanic Gardens before removal of explants. Bar $=2 \mathrm{~cm}$

Table 1. Response of in vitro shoots and leaves of Grevillea scapigera to medium supplemented with plant growth regulators. ${ }^{\mathrm{z}}$

\begin{tabular}{|c|c|c|}
\hline Explant & $\begin{array}{l}\text { Growth } \\
\text { regulators } \\
(\mu \mathrm{M})\end{array}$ & $\begin{array}{c}\text { Mean no. } \\
\text { shoots/ } \\
\text { explant } \\
\pm \mathrm{SE}^{\mathrm{y}}\end{array}$ \\
\hline Shoots $y$ & $\begin{array}{l}0.5 \mathrm{BA} \\
0.5 \mathrm{BA}+5.0 \text { kinetin }\end{array}$ & $\begin{array}{l}2.4 \pm 0.1 \\
5.8 \pm 0.2\end{array}$ \\
\hline Leaves $^{x}$ & $10.0 \mathrm{BA}+0.5 \mathrm{IBA}$ & $3.0 \pm 0.2$ \\
\hline
\end{tabular}

${ }^{2}$ Shoots incubated on WPM, leaves on 1/2 MS.

${ }^{y}$ Minimum of 20 replicates, repeated at least twice.

'Seven replicates.

Skoog, 1962) basal mineral salts, $100 \mu \mathrm{M}$ sodium ferric EDTA, $500 \mu \mathrm{M}$ myo -inositol, WPM vitamins, $90 \mathrm{~mm}$ sucrose, $10 \mathrm{~g}$ agar/ liter, and supplemented with $10 \mu \mathrm{M} \mathrm{BA}$ and $0.5 \mu \mathrm{M}$ IBA. In studies with leaf cultures of Hibbertia miniata C.A. Gardner and Asterolasia species (unpublished data), contact with the medium appeared to be essential for adventitious bud development. Thus, leaves of G. scapigera were firmly pressed onto the medium surface, which proved difficult as the leaves are coriaceous, undulate, and hence difficult to flatten despite being grown in vitro.

After 19 to 21 days of incubation, leaves began to swell, and shoot growth commenced 9 to 14 days later (Fig. 2). Adven-

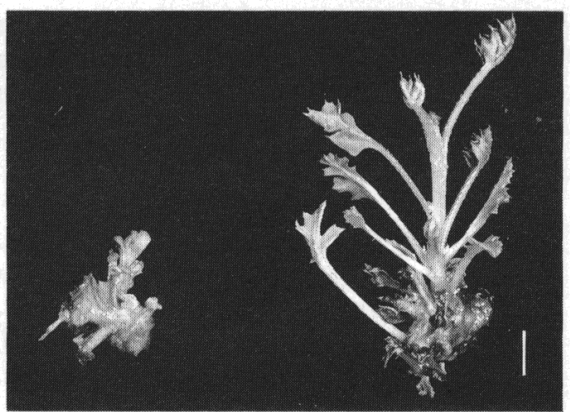

Fig. 2. Adventitious shoot production from excised leaves of in vitro-grown Grevillea scapigera 3 weeks (left) and 5 weeks (right) after initial culture. $\mathrm{Bar}=0.3 \mathrm{~cm}$.

titious shoots appeared mainly from the cut distal petiole end and where the leaf perimeter was in contact with the medium. After 7 weeks of incubation, 15- to 20-mm-long shoots had formed on seven of nine leaf cultures. Shoots were then elongated and treated as for shoot-derived cultures. For a single leaf $\left(0.7 \mathrm{~cm}^{2}\right)$, an average of three adventitious shoots were formed and ready for subculture after 6 to 7 weeks (Table 1). On average, eight to 12 larger leaves ( 0.5 to 0.8 $\mathrm{cm}^{2}$ ) were produced per explant per culture period, of which up to half could be used for leaf cultures.

Elongated shoots, $\approx 30$ to $50 \mathrm{~mm}$ long, were acclimatized by placing shoots in culture vessels in a glasshouse (with $70 \%$ shade) for several days. Shoots were separated and dipped in $0.15 \%$ aqueous propyl[3-(dimethylamino)propyl]carbamate (propamocarb) antifungal solution. The stem bases were then dipped in a commercial softwood cutting powder containing $0.1 \%(\mathrm{w} / \mathrm{w})$ IBA and placed in a mix of equal parts pasteurized brown peat and unpasteurized perlite in trays of pots of 40-ml capacity (64 per tray). The shoots were kept under fogged conditions for 2 weeks then moved to intermittent misting for a further 2 to 3 weeks or until roots were visible. Plants were then repotted into $70 \times$ $70 \times 100-\mathrm{mm}$ tapered pots of $400-\mathrm{ml} \mathrm{ca}-$ pacity (Fig. 3), with potting mix containing equal parts composted wood fines : coarse sand : perlite, supplemented with inorganic fertilizer $(17 \mathrm{~N}-1.6 \mathrm{P}-8.7 \mathrm{~K})$, and pasteurized at $70 \mathrm{C}$ for $1 \mathrm{~h}$.

In vitro rooting was superseded by the ease and success of using microcuttings. Microcuttings rooted readily in potting mix, with some initiating roots in less than 2 weeks. Most $(67 \%) G$. scapigera shoots rooted in

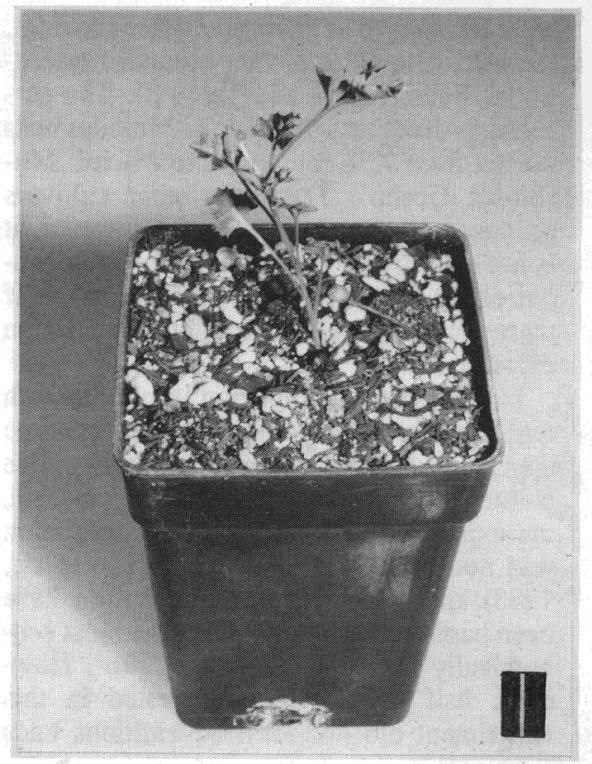

Fig. 3. Grevillea scapigera 6 months after removal from culture to potting mixture. Bar = $0.8 \mathrm{~cm}$.

$<5$ weeks. After 6 months, shoots of $G$. scapigera produced healthy plants 10 to 12 $\mathrm{cm}$ tall (Fig. 3). Several plants flowered 9 to 12 months after transfer from culture.

This paper outlines methods for rapid propagation of the rare and endangered species Grevillea scapigera, including a method for adventitious shoot production from leaf material-a new method for propagation in the Proteaceae with possible commercial applications. However, the limited genetic material available to the study does not favor successful reconstitution of the species in the natural habitat. The genetic constitution of plants derived from basal shoot clusters and leaves is unknown. Thus, the suitability of plants generated from these sources for habitat re-establishment trials requires careful assessment. The recent discovery of further plants of G. scapigera does hold promise for greater genetic variation than previously existed for the propagation program.

\section{Literature Cited}

Lloyd, G.B. and B.H. McCown. 1981. Commercially-feasible micropropagation of mountain laurel, Kalmia latifolia, by use of shoot-tip culture. Proc. Intl. Plant Prop. Soc. 30:421-437.

Murashige, T. and F. Skoog. 1962. A revised medium for rapid growth and bio-assays with tobacco tissue cultures. Physiol. Plant. 15:473497. 